\title{
The Financing Situation of Small and Medium-sized Enterprises in Inner Mongolia and Countermeasure Research
}

\author{
Zhu Chen ${ }^{1}$ \\ ${ }^{1}$ School of Finance, Inner Mongolia Finance and Economics University, Hohhot 010070, China
}

\begin{abstract}
The development of small and medium-sized enterprises in Inner Mongolia is a new growth area of the Inner Mongolia economy, but compared with developed countries and regions, there is still a large disparity; the financing difficulty is eminent. Causes of financing difficulties of small and medium-sized enterprises in Inner Mongolia mainly displays in three aspects: the development environment, the enterprise itself, and financial institutions. Therefore one should construct from financial service system, the government support, as well as improving the quality of the enterprise itself and the quality of management in order to solve the financing difficulties of small and medium-sized enterprises.
\end{abstract}

Keywords: Inner Mongolia, small and medium-sized enterprises, financing system

\section{Introduction}

Small and medium-sized enterprises are not only an important part of the national economy, but also an important factor in the development of the economy of Inner Mongolia. The current problem of financing difficulty has become the most prominent problem faced by small and medium-sized enterprises. So far, small and medium-sized enterprises in Inner Mongolia have created more than $50 \%$ of tax revenue, more than $60 \%$ of GDP, more than $60 \%$ of technical innovation, provides more than $80 \%$ of job positions, and more than $90 \%$ of newlyadded job positions; in promoting economic growth, absorbing the urban and rural employment, promoting the construction of the people's livelihood, small and medium-sized enterprises play an irreplaceable role. Construction of the small and medium-sized enterprise financing system in Inner Mongolia, therefore, is not only needed to promote the development of the enterprise itself, but also needed a strong driving force to promote the development of economy in Inner Mongolia.

Small and medium-sized enterprises are numerous in Inner Mongolia and have a large economic aggregate, so they become an important support to the economic development of Inner Mongolia. Small and medium-sized enterprises in Inner Mongolia are spread through all 12 union cities; by the end of 2012, there are 1.086 million small and medium-sized enterprises and individual businesses in Inner Mongolia, taking 95\% of the total market main body, in which there are 175000 small and medium-sized enterprises, accounting for $99 \%$ of the total number of enterprises, and distributed in the primary industry, secondary industry and tertiary industry, divided into 16 industries according to the 2011 new small and medium-sized enterprise standard. The development of small and medium-sized enterprises in Inner Mongolia are directly connected to the livelihood of the people, thus has a very important strategic position. According to relevant data, small and medium-sized enterprise created in Inner Mongolia around $70 \%$ of GDP, more than $70 \%$ of the tax revenue, and provides more than $80 \%$ of all jobs and more than $90 \%$ of new jobs.

Looking from the perspective of the various administrative areas of the district, small and mediumsized enterprises spread all over the region. The number of small and medium-sized enterprises is: In Hohhot 20498, in Baotou 23328, in Ordos City 17014, in Hulun Buir City 20892, in Tongliao 16933, in Hinggan League 8451, in Chifeng City 27000, in Xilingol League 8490, in Ulanchap 11750, in Bayinnaoer City 7000, in Wuhai City 4420, in Alxa League 3404.

Looking from the industry distribution of small and medium-sized enterprises, the number of small and medium-sized enterprises engaged in the first industry (industrialized agriculture and animal husbandry) are 2100 , accounts for the proportion of $1.2 \%$; those engaged in mining, manufacturing, the second industry of small and medium-sized enterprise count up to 25025 in number, accounts for the proportion of $14.3 \%$; the number of small and medium-sized enterprises engaged in the service sector accounts for nearly $85 \%$ of the proportion. In 2012, small and medium-sized enterprise had an industry added value of 474.371 billion yuan, in which small and medium-sized enterprises above designated size added 328.265 billion yuan, accounting for $69.2 \%$; Under-scale industrial enterprises and individual business units achieved gross value of industrial output 146.106 billion yuan, accounting for $30.8 \%$.

However, various problems still exist in the process of the development of small and medium-sized enterprises, such as the environment of regional policy and the enterprise's own weak development ability, especially when the "financing difficulties" problem is the key factor to preventing small and medium-sized enterprises from rapid expansion and improving quality; this becomes a bottleneck to the further development of small and medium-sized enterprises. Under the condition of the interest rate control, state-owned financial institutions to 
control most of the money, a lot of money is configured to inefficient projects, which greatly limits the development of small and medium-sized enterprises. According to a survey of the Chinese Academy of Social Sciences, state-owned large and medium-sized enterprises in China create only $30 \%$ output but take up more than $70 \%$ of bank credit; and yet small and medium-sized enterprises that create $70 \%$ of the industrial added value, and provides more than $95 \%$ of all jobs as well as $95 \%$ of economic growth, only got $30 \%$ of the bank loans. "Financing difficulty" becomes a problem that need to be addressed during the development of small and medium-sized enterprises.

\section{Financing status of small and medium-sized enterprises in Inner Mongolia}

Inner Mongolia's banking financial institutions set up specialized loan institutions for small and medium-sized enterprises, constantly expanding the coverage of small and medium-sized enterprise financial services, and had new developments in the construction of small and medium-sized enterprise financial service mechanisms. In 2007 among financial institutions of the entire district, loan balances in the small and medium-sized enterprises is 60.43 billion yuan, accounts for $16 \%$ of the balance of loans of all financial institutions; small and medium-sized enterprise loans account for $8 \%$ of all the new loans that year. By the end of 2012, the small and medium-sized enterprise loan balance in the district reaches 465.336 billion yuan, accounting for $41.2 \%$ the proportion of loan balance for all financial institutions; small and mediumsized enterprise loan during that year accounted for $42.8 \%$ of all new loans. Loan balance growth increased 6.7 times in five years, the proportion of small and medium-sized enterprise loan balance of all financial institutions increased by $25.2 \%$; small and medium-sized enterprise loan increased by $34.8 \%$ among all new loans during that year.

As an important part of small and medium-sized enterprise financial services, the local banking financial institutions in Inner Mongolia received rapid development in recent years. There are a total of 157 local corporate banking financial institutions in Inner Mongolia, including 4 city commercial Banks, 97 rural credit cooperatives legal institutions at the county level, 59 new-type rural financial institutions such as the village bank, and 2 trust and investment companies; these formed a local financial services system that is rather complete in variety and spreads over a relatively large area. The local banking financial institutions of Inner Mongolia is an important part of the small and mediumsized enterprise financial services, focusing on services for small and medium-sized enterprises. The local banking financial institutions uses more than $90 \%$ of the loan balance to provide financial service for small and medium enterprises.

Inner Mongolia is the one of the first five provincial regions in China to have experimental small loan companies. For the past five years, small loan company develop rapidly in the region; the number of small loan companies and their registered capital scales are among the leading ranks in the country. Small loan companies increased from five in 2007 to 533 in 2012, and the registered capital increased from 300 million yuan in 2007 to 40.25 billion in 2012; at the end of 2012 the loan balance is 38.6 billion yuan, five-year issued loan total is 149.99 billion yuan; it has become an important new force for the substantial economies such as inclusive finance, services for small micro enterprises, individual businesses, and farming businesses.

Guarantee system of small and medium enterprises in Inner Mongolia developed fairly fast. Number of financing guarantee agencies increased from 82 in year 2007 to 212 in year 2012; warranty balance increased from 2.48 billion yuan in 2007 to 33.6 billion yuan in 2012; guarantee funds increased from 1.92 billion yuan in 2007 to 19 billion yuan in 2012. At the end of 2012 the guarantee liability balance is 34 billion yuan, and the 2012 newly-added guarantee is 30.7 billion yuan. At the end of 2012 in Inner Mongolia, financing guarantee agencies for small micro enterprise loan guarantee is 12.3 billion yuan, accounting for $48 \%$ of the total enterprise loan guarantees.

From the above data, it is evident that Inner Mongolia financing situation is gradually improving from year to year; but it still cannot fulfill the need for rapid development of small and medium enterprises. Small and medium enterprises still face many problems in the matter of financing.

\section{Financing difficulties of small and medium enterprises in Inner Mongolia}

In recent years, small and medium-sized enterprises play an irreplaceable role in promoting urban and rural economic development in Inner Mongolia, increasing employment, and improving the residents' quality of life. The development speed of small and medium-sized enterprises increases day by day, but the problem of financing which emerges during the development process of small and medium-sized enterprises is still a significant issue that restricts the development of small and medium-sized enterprises.

\subsection{Problems existing in the developing environment}

Administrative departments of small and medium-sized enterprises in Inner Mongolia are numerous, economic commission, industrial and commercial bureau and other departments are all involved in the management of small and medium-sized enterprises from different perspectives, and department policies are not unified; this causes inconsistencies among the execution rules of small and medium-sized enterprises, leading to self-centered working situations of many functional departments which significantly increases the proportion of operating costs in small and medium-sized enterprises. Even though Inner Mongolia has issued many policies in order to promote the development of small and medium-sized enterprises, such as "Opinions on Promoting the 
Industrial Development of Small and Medium-sized Enterprises" and "Opinions on Promoting Sustained Healthy Development of Small Miniature Enterprises," it still lacks operational support and protection regulations.

\subsection{Problems existing in the Enterprises themselves}

(1) Due to that the small and medium-sized enterprise operation and management system is not sound, and that it lacks efficient and well-trained management, the overall internal personnel quality is low. Among the managers of small and medium-sized enterprises in Inner Mongolia, few had degrees of college level or above; small and medium-sized enterprise management level is relatively low. Lack of transparency in the small and medium-sized enterprise information, as well as lack of public credibility in society, all led to the financing difficulties of small and medium-sized enterprises.

(2) Most small and medium-sized enterprises do not have appropriate financing plans, the enterprises cannot achieve a deep understanding of their own problems; most pursue financing targets, concerning only the present, and fail to make good long-term goals; they do not make better analysis of the market, their own products, or future prospective, and the lack of trust is a common attitude that financial institutions such as banks have towards small and medium enterprises. Thus to some extent, the financing ability of small and mediumsized enterprises is limited by a lot.

(3) Small and medium-sized enterprises lack sufficient security guarantees. Scales of small and medium-sized enterprises are small, the capital is insufficient, lacking fixed assets and equipments that can be used as collateral. They do not have enough security guarantees, so they could not obtain the trust of the bank and other financial institutions, and this makes it difficult to get loans.

\subsection{Problems in financial institutions}

Small and medium-sized enterprises have a relatively small scale, the capital is insufficient and credit consciousness is low, thus the lending-costs of financial institutions towards small and medium-sized enterprises is high. The trend that financial institutions favor large enterprises and neglect small enterprises is prominent. In addition, due to mismatching information between stateowned banks and small and medium-sized enterprises, banks cannot obtain correct information from small and medium enterprise customers, causing their lack of trust towards small and medium enterprises and thus further exacerbating the financing difficulties of small and medium-sized enterprises. At the same time, most of the small and medium-sized enterprises are unable to obtain loans because they could not meet requirements of the bank loan conditions.

\section{Solutions to the financing difficulties of small and medium enterprises in Inner Mongolia}

To improve the financing difficulties of small and medium-sized enterprises, various comprehensive efforts are needed to fully eradicate the problem. In summary, financial systems should provide better service to small and medium-sized enterprises, the government should actively create opportunities, and small and mediumsized enterprises should regulate themselves. Only when these three parties work together can we effectively relieve the conflicts in financing problems faced by small and medium-sized enterprises.

\subsection{Complete the financial service system for small and medium enterprises}

To improve the financing difficulties, we need to create suitable and diversified financial service systems according to the financing needs of small and medium enterprises in different developing stages.

(1) Develop a venture capital fund as an initial-stage financing for small and medium enterprises. First, we need to develop a venture capital fund that focuses on private capital, in order to rapidly increase the total amount of venture capitals and form a diversified main body that participates in venture capitals, thus satisfying the financing needs of innovative developments of small and medium enterprises in China. Secondly, establish and improve the exit mechanism of venture capital; going public is undoubtedly the best way to achieve appreciation for the venture capital. Finally, establish a relevant system of preferential policies, encourage longterm value investment, and curb short-term speculation, in order to rationalize the investment behavior of venture capitals.

(2) Strengthen the banking service function for the growth-stage financing of small and medium-sized enterprises. To ease the financing difficulties of small and medium-sized enterprises, we must attach great importance to the role of the banking service for small and medium-sized enterprises. We need to further improve financial service mechanisms of large banks to small and medium-sized enterprises. The small and medium enterprise financing service sector of the Minsheng Bank of China (CMBC) is well worth promoting and learning from. We need to have a widespread implementation of this financing service sector system in the large commercial banks and national shareholding commercial banks, establish and perfect the performance of an incentive mechanism, a risk control mechanism and a bad verification mechanism different from the financing services of large customers; and develop financing tools and products that can meet the needs of its financing needs, as well as innovate new means of credit extension and guarantees.

(3) Use the capital market to broaden mature-stage enterprise financing channels. Accelerate and promote the small and medium-sized enterprise public listing restructuring. Guide and support small and medium-sized enterprises that have good growth and high technology content to achieve direct financing via markets of the small and medium enterprise board and the growth enterprise market board; support qualified small and medium-sized enterprises to be listed overseas. In addition to the channel of listed financing, we can encourage small and medium-sized enterprises to achieve financing on the bond market. 


\subsection{Complete the financial service system for small and medium enterprises}

In recent years, though the "money shortage" problem of small and medium-sized enterprises in our country under the efforts of the government at all levels have showed a certain result, the existing policy is insufficient to affect a radical cure of small and medium-sized enterprise financing difficulties. The government should clarify existing policies, strengthen policy coordination, reduce some unreasonable policy constraints, to try and improve the efficiency in using the fiscal fund.

(1) Give differentiation regulation to small and medium-sized enterprise financial businesses. To encourage commercial banks put more credit operations towards small and medium-sized enterprise, the state should establish differentiated regulation systems to improve the tolerance of non-performing loans to small enterprises.

(2) Strengthen the construction of the small and medium-sized enterprise credit system. The information mismatch between the commercial banks and small and medium-sized enterprises is also the one important reason for financing difficulties; relying on the government to establish a credit system suitable for local Inner Mongolia can effectively relieve the conflict. For instance, the government can set up a local small and medium-sized enterprise information base and establish credit standards and financing access standards for small and mediumsized enterprises, and collectively rank the small and medium enterprises in terms of credit, efficiency, standardization, growth, growth potential, etc; commercial banks can choose small and medium-sized enterprises according to their standards and provide key support.

(3) Set up small micro enterprise loan risk compensation fund. Practice shows that to set up small micro enterprise loan compensation funds is a way to increase the small micro enterprise loan and dissolve the loan risk and loss of the bank loaning to small micro enterprises; it can effectively arouse the enthusiasm and innovation of bank services to small micro enterprises.

\subsection{Improve the quality level as well as operation and management level of small and medium- sized enterprises}

While there is no way to change the outside financial environment during financing of small and medium-sized enterprises, the enterprise itself can take the initiative to do some preparation, such as expanding enterprise scale, enhance profitability, improve the enterprise's financial system, etc. Although the small and medium-sized enterprise financing is more difficult, it is in a state that cannot be eased or harmonized, and not all small and medium enterprises are experiencing financing difficulties. Small and medium-sized enterprise leaders of enterprises weak and backward in management can learn from well-developing small and medium-sized enterprises in order to improve the overall quality of small and medium-sized enterprises. To obtain outside financial support, it is necessary for small and medium- sized enterprises to improve their overall abilities, to harden their skills while studying from outside, find the accurate market positioning for themselves, strengthen their own accumulation ability, improve the management level of small and medium-sized enterprises, and improve competitiveness.

\subsection{Construct a platform of communication between the government, the enterprise, and the bank}

We can set up a convenient platform connecting enterprises, government, and bank, by occasionally holding joint meetings of the three. Among the three, the government really play a role of guidance, carrying out the policies that could be of benefit to small and mediumsized enterprises, and guide, supervise the bank lending to small and medium-sized enterprises, as well as arrange fixed capital investment in small and medium-sized enterprises and strengthen the support services of financial institutions for small and medium-sized enterprises. Financial institutions, under the guidance of the government, can set a reasonable proportion of lending to small and medium enterprises to help the development of small and medium-sized enterprises.

\section{Conclusions}

On the present small and medium-sized enterprises in Inner Mongolia, financing difficulties is a primary and key problem troubling the development of small and medium-sized enterprises. Studies find that the causes of financing difficulties of small and medium-sized enterprises in Inner Mongolia are various, it is not only due to problems of the enterprises themselves but also can involve reasons due to the state, the society, the policies of local government, and financial institutions, etc. Therefore, the solution to financing difficulty problems of small and medium-sized enterprises in Inner Mongolia cannot rely on one source. It is a systematic project, and only gathering up the threads together can it be fundamentally solved, promoting both the fast and good development of small and medium-sized enterprises, and leading to a sustained, stable, healthy and rapid development of the Inner Mongolia economy.

\section{References}

[1] Ding Xiaoli, “A study and countermeasure analysis of the financing problems of small and medium-sized enterprises in China," Beijing: China Economic Publishing House, 2013.8.1.

[2] Kong Delan. "A study on the financing structure and financing strategies of small and medium-sized enterprises," Beijing: China Financial Economic Publishing House, 2009.4.1.

[3] Mao Wenjing, "The current development of small and medium-sized enterprises in Inner Mongolia and countermeasure research," China Township Enterprises Accounting, pp. 114-115, 2013.

[4] Li Xuemin and Yongfeng Qiao, "About the financing problems of small and medium-sized enterprise in 
Inner Mongolia," China Township Enterprises Accounting, pp. 30-31,2013.

[5] Tian Yuan and Juan Ju, "An exploration of the 'money shortage' problem in enterprises and the countermeasures," Economics and Management, pp. 29-36, 2013.
[6] Lin Hanchuan and Anyu Li, "A research report on the development of small and medium-sized enterprises in China, 2011," Beijing: Enterprise Management Publishing, 2012.2.1.

[7] Inner Mongolia Autonomous Region Bureau of Statistics, "The Inner Mongolia Statistics Yearbook 2012,” Beijing: China Statistics Press, 2013.10. 